\title{
RECHTSVACUUM ATAS PENGATURAN KEKUASAAN PEMBINA YAYASAN
}

\section{Fajar Rachmad Dwi Miarsa ${ }^{1}$ dan Cholilla Adhaningrum Hazir ${ }^{2}$}

${ }^{1}$ Fakultas Hukum, Universitas Maarif Hasyim Latif

Email:fajar_rahmad@dosen.umaha.ac.id

${ }^{2}$ Fakultas Hukum, Universitas Negeri Surabaya

Email: cholillaadhaningrumhazir@gmail.com

\begin{abstract}
The foundation is a legal entity that is private and run without profit (profit oriented). There are three organs that run a Foundation, namely Builders, Managers and Supervisors. The organ that is responsible for running the Foundation so that the purpose and purpose of the foundation of the Foundation which is social, religious, and humanitarian can be realized. Establishment of Law Foundation Number 16 of 2001 on the Foundation. The regulation contains the norm vacancy (rechtsvacuum) in the regulation of Foundation Builders. The problematic form of authority possessed by the Founders of the Foundation, seems to be infinite (absolute) and there is no arrangement for the termination of the Builder. The purpose of this writing is to analyze the form of vacancy norms of Law No. 16 of 2001 on the Foundation regarding the authority held by the Founders of the Foundation. Based on the description, then the problem is what are the consequences of juridis rechtsvacuum on Law Number 16 of 2001 on the Foundation on the form of responsibility of the Builder? This writing uses the writing method used is the normative juridical writing that is all the activities of a person to answer legal issues that are academic and practical, using a legal approach (Statute Approach), and a conceptual approach (Conceptual Approach) with prescriptive writing that gives a description or formulate problems in accordance with existing circumstances / facts. The author uses this method to provide an argument for the results of the writing done by the author. The results of the writing on the legal consequences of the form of problem solving on the form of arbitrariness of the Founders of the Foundation due to the vacancy of rules (rechtsvacuum) on Law No. 16 of 2001 on the Foundation.
\end{abstract}

Keywords: Norm vacancy, builder, foundation.

\begin{abstract}
ABSTRAK
Yayasan merupakan badan hukum yang bersifat privat dan dijalankan dengan tidak mencari keuntungan (profit oriented). Terdapat tiga organ yang menjalankan suatu Yayasan, yaitu Pembina, Pengurus dan Pengawas. Organ tersebut yang bertugas menjalankan Yayasan agar tujuan dan maksud pendirian Yayasan yang bersifat sosial, keagamaan, dan kemanusiaan dapat terwujud. Pembentukan Yayasan diatur dalam Undang-Undang Nomor 16 Tahun 2001 tentang Yayasan. Peraturan mengandung kekosongan norma (rechtsvacuum) pada pengaturan mengenai Pembina Yayasan. Problematika bentuk kewenangan yang dimiliki Pembina Yayasan, terkesan tanpa batas (absolute) dan tidak terdapat pengaturan mengenai pemberhentian Pembina. Tujuan penelitian ini adalah menganalisis bentuk kekosongan norma Undang-Undang Nomor 16 Tahun 2001 tentang Yayasan mengenai kewenangan yang dimiliki Pembina Yayasan. Berdasarkan pada uraian tersebut, maka permasalahannya adalah apa akibat yuridis rechtsvacuum atas Undang-Undang Nomor 16 Tahun 2001 tentang Yayasan mengenai bentuk tanggungjawab Pembina? Penelitian ini menggunakan metode penelitian yang digunakan adalah penelitian yuridis normatif yaitu segala aktivias seseorang untuk menjawab permasalahan hukum yang bersifat akademik dan praktis, dengan menggunakan pendekatan perundang-undangan (Statute Approach), dan pendekatan konseptual (Conceptual Approach) dengan penelitian preskriptif yaitu memberikan gambaran atau merumuskan masalah sesuai dengan keadaan/fakta yang ada. Penulis menggunakan metode ini untuk memberikan argumentasi atas hasil penelitian yang dilakukan penulis. Hasil penelitian mengenai akibat yuridis terhadap bentuk penyelesaian masalah mengenai bentuk kesewenang-wenangan Pembina Yayasan karena adanya kekosongan aturan (rechtsvacuum) atas Undang-Undang Nomor 16 Tahun 2001 tentang Yayasan.
\end{abstract}

Kata Kunci: Kekosongan norma, pembina, yayasan. 


\section{PENDAHULUAN}

\section{Latar Belakang}

Indonesia adalah negara hukum (rechtsstaat) yang menerapkan kaidah hukum untuk menjadi dasar terhadap masyarakat dalam segala tingkah laku, sikap, dan perbuatannya. Hal ini berlandaskan pada Pasal 1 ayat (3) Undang-Undang Dasar Negara Republik Indonesia Tahun 1945 (selanjutnya disebut UUD 1945) berbunyi:

"negara Indonesia adalah negara hukum"

Hukum yang mengatur hak dan kewajiban manusia termuat dalam hukum perorangan. Hukum perorangan menurut Van Apeldoorn, disebut juga hukum purusa adalah seluruh peraturan tentang purusa (subyek-subyek hukum), dan mempunyai peraturan kewenangan hukum (rechtbevoegdheid) dan kewenangan bertindak (handelingsbevoegheid) (Simanjuntak, 2015) Manusia sebagai subjek hukum, secara umum subjek hukum (rechtsubject) diartikan sebagai pendukung hak dan kewajiban yaitu, manusia dan badan hukum (Tutik, 2008) Badan hukum merupakan orang yang telah diciptakan oleh hukum. Salah satu badan hukum yang menjadi bahan penelitian adalah Yayasan.

Pendirian Yayasan di Indonesia sudah ada sejak zaman Belanda. Penyebutan istilah Yayasan berbeda-beda yaitu stichgen, stichting, gesticnen dar armeneh, richtingen (Ais, 2000). Yayasan di Indonesia berdiri atas dasar Undang-Undang Nomor 28 Tahun 2004 Tentang Perubahan Atas Undang-Undang Nomor 16 Tahun 2001 tentang Yayasan. Yayasan dalam pendiriannya diatur oleh 3 organ, yaitu Pembina, Pengurus dan Pengawas. Dalam bergulirnya reformasi, Undang-Undang Nomor 16 Tahun 2001 tentang Yayasan belum dapat memenuhi kebutuhan perkembangan hukum dan terdapat substansi (isi) peraturan yang menimbulkan multitafsir (kabur) serta kekosongan norma.

Pengaturan mengenai 3 organ yang menjalankan Yayasan telah diatur dalam Undang-Undang Nomor 16 Tahun 2001 tentang Yayasan beserta Peraturan Pemerintah Nomor 3 Tahun 20013 Tentang Perubahan Atas Peraturan Pemerintah Nomor 63 Tahun 2008 Tentang Perlaksanaan Undang-Undang Tentang Yayasan, tetapi pengaturan tentang Pembina setelah ditelaah dalam peraturan tersebut terdapat kekosongan norma (rechtsvacuum) mengenai pengaturan kekuasaan yang dimiliki Pembina yang terkesan absolute (mutlak) dan pemberhentian Pembina yang tidak diatur dalam peraturan tersebut. Terdapat banyak problematika yang diangkat mengenai bentuk kesewenangan Pengurus dan Pengawas dalam mengatur Yayasan, karena terdapat aturan mengenai permasalahan tersebut secara tegas. Tetapi apabila yang melakukan penyalahgunaan kewenangan adalah Pembina Yayasan, yang notabennya dapat dianggap sebagai pendiri dan memiliki kekuasaan tanpa batasan pemberhentian. Bagaimana hukum dapat menunjukkan keadilan, kepastian dan kemanfaatannya, apabila kewenangan yang dimiliki Pembina tidak terikat aturan hukum.

\section{Rumusan Masalah}

Rumusan masalah dari latar belakang tersebut adalah apa akibat yuridis rechtsvacuum atas Undang-Undang Nomor 16 Tahun 2001 tentang Yayasan mengenai bentuk tanggungjawab Pembina? 


\section{METODE PENELITIAN}

Metode penelitian yang digunakan adalah penelitian yuridis normatif (penelitian hukum). Yuridis normatif adalah segala aktivitas seseorang untuk menjawab permasalahan hukum yang bersifat akademik dan praktis, yang bersifat asas-asas hukum, norma-norma hukum yang hidup dan berkembang dalam masyarakat atau berkenaan dengan kenyataan hukum dalam masyarakat (Ali, 2014). Pendekatan yang digunakan yaitu pendekatan perundang-undangan (Statute Approach), dan pendekatan konseptual (Conceptual Approach). Pendekatan perundang-undangan dengan menggunakan peraturan perundang-undangan sebagai landasan melakukan analisis. Pendekatan konseptual adalah penulis akan menemukan gagasan-gagasan yang melahirkan pengertian, konsep, dan asas-asas hukum yang relevan dengan permasalahan yang diteliti (Marzuki, 2013).

Metode penelitiannya dengan preskriptif, yaitu memberikan gambaran atau merumuskan masalah sesuai dengan keadaan/fakta yang ada. Penulis menggunakan metode ini untuk memberikan argumentasi atas hasil penelitian yang dilakukan penulis dengan cara menganalisis peraturan yang ada terkait dengan masa jabatan Pembina Yayasan.

\section{HASIL DAN PEMBAHASAN}

Pendirian Yayasan di Indonesia, pada awalnya hanya berdasarkan kebiasaan yang ada dalam masyarakat. Perkembangan kegiatan masyarakat yang menjadikan pembentukan peraturan perundang-undangan tentang Yayasan, bertujuan untuk menjamin kepastian dan ketertiban hukum agar Yayasan berfungsi sesuai dengan maksud dan tujuan nya yaitu berdasar pada prinsip keterbukaan dan akuntabilitas kepada masyarakat. Oleh karena itu, dibentuklah landasan hukum tentang pendirian Yayasan dengan Undang-Undang Nomor 16 Tahun 2001 tentang Yayasan yang selanjutnya diubah dengan Undang-Undang Nomor 28 Tahun 2004 tentang perubahan atas Undang-Undang Nomor 16 Tahun 2001 tentang Yayasan. Undang-Undang Yayasan tersebut pada prinsipnya menghendaki Yayasan bersifat terbuka dan pengelolaannya bersifat professional. (Simatupang, 2016).

Pengertian Yayasan diatur dalam Pasal 1 Undang-Undang Nomor 16 Tahun 2001 tentang Yayasan, yang berbunyi:

"Yayasan adalah badan hukum yang terdiri atas kekayaan yang dipisahkan dan diperuntukkan untuk mencapai tujuan tertentu di bidang sosial, keagamaan, dan kemanusiaan, yang tidak mempunyai anggota"

Yayasan adalah salah satu badan hukum. Menurut Sofwan (1964) menyatakan bahwa badan hukum adalah kumpulan dari orang-orang yang Bersama-sama mendirikan suatu badan (perhimpunan) dan kumpulan harta kekayaan, yang ditersendirikan untuk tujuan tertentu (Yayasan). Baik perhimpunan maupun Yayasan kedua-duanya berstatus sebagai badan hukum, jadi merupakan persoon, pendukung hak dan kewajiban. Badan hukum adalah suatu badan yang ada karena hukum dan memang diperlukan keberadaannya sehingga disebut legal entity, artificial person atau manusia buatan, atau personal in law atau legal person/rechtsperson. Jadi di samping manusia (natuurlijk person), ada manusia lain yang disebut rechtspersoon yang merupakan orang tiruan atau orang yang diciptakan hukum (Simatupang, 2016). Suatu badan hukum mulai menjadi subjek hukum saat badan hukum tersebut disahkan oleh undang-undang dan berakhirnya badan hukum tersebut, ketika dinyatakan pailit oleh pengadilan (bubar). Oleh karena itu, dalam pendirian badan hukum terdapat beberapa persyaratan yang harus dipenuhi diantaranya: (a) adanya harta kekayaan yang terpisah dari kekayaan orang perseorangan yang bertindak; (b) adanya suatu tujuan tertentu; (c) adanya suatu kepentingan sendiri dari kelompok orang; dan (d) adanya suatu organisasi yang teratur. 
Pemahaman badan hukum sebagai subjek hukum dari berbagai pandangan pendapat dan teori, yaitu: (a) teori fiksi (fictie theorie), Freidrich Carl Von Savigny (dalam Syahrani, 1992) berpendapat bahwa hanya manusia yang dapat menjadi subjek hukum, sedangkan badan hukum dikatakan sebagai badan hukum hanyalah fiksi, yaitu sesuatu yang sebenarnya tidak ada tetapi orang menghidupkannya dalam bayangannya untuk menerangkan sesuatu hal. Badan hukum itu semata-mata buatan negara; (b) teori harta kekayaan bertujuan (doel vermogenstheorie), Brinz dan Van der Heijden menyatakan bahwa manusia yang dapat menjadi subjek hukum, tetapi ada kekayaan yang bukan merupakan kekayaan seseorang tetapi kekayaan itu terikat pada suatu tujuan tertentu. Kekayaan yang tidak ada yang mempunyainya dan terikat tujuan tertentu. Badan hukum diberi kedudukan sebagai orang karena memiliki hak dan kewajiban-kewajiban kepada pihak ketiga (Tutik, 2008); (c) teori organ (orgaan theorie), Otto von Gierke menyatakan badan hukum adalah organ seperti halnya manusia, yang menjelma dalam pergaulan hukum, yang dapat menyatakan kehendak melalui alat-alat perlengkapan yang ada padanya (Pengurus dan anggotaanggotanya) seperti halnya manusia yang ber panca indera. Oleh karena alat-alat (organen) itu berupa orang-orang manusia juga, maka sudah selayaknya syarat-syarat dalam peraturan-peraturan hukum yang melekat pada badan seorang manusia itu, dapat dipenuhi juga oleh badan hukum (Prodjodikoro, 1992); (d) teori kekayaan Bersama (propriete collective theorie), Planiol menyatakan hak dan kewajiban badan hukum pada haikatnya adalah hak dan kewajiban anggota Bersama-sama. Sehingga antara anggota dan badan hukum Bersama-sama pula dalam hal bertanggung jawab. Harta kekayaan badan hukum adalah milik anggota-anggota. (Aswaratika, 2018); (e) teori harta karena jabatan (theorie van het ambtelijk vermogen), horder dan binden menyatakn bahwa badan hukum ialah suatu badan yang mempunyai harta yang berdiri sendiri yang dimiliki badan hukum itu, tetapi oleh Pengurusnya dank arena jabatannya, ia diserahkan tugas untuk mengurus harta tersebut (Kansil, 1991); dan (f) teori kekayaan yuridis (juridische realiteitsleer), E. M Meijers dan Paul Scholten (dalam Syahrani, 1992) berpendapat hukum tidak dapat diraba, bukan khayal tetapi suatu kenyataan yuridis. Mempersamakan manusia dengan badan hukum itu terbatas pada bidang hukum saja (Syahrani, 1992).

Bentuk badan hukum menurut Simanjuntak (2015) terbagi atas dua, yaitu: (a) badan hukum publik (publiek rechtspersoon) adalah badan hukum yang didirikan oleh negara untuk kepentingan publik/negara; dan (b) badan hukum privat (privaat rechtspersoon) adalah badan hukum keperdataan yang didirikan untuk kepentingan individu, badan hukum privat merupakan badan hukum milik swasta yang didirikan oleh individu-individu untuk tujuan tertentu dan berlandaskan pada aturan yang ada. Perbedaan badan hukum privat dan publik dapat dilihat dari cara pendiriannya sebagaimana diatur dalam Pasal 1653 Kitab Undang-Undang Hukum Perdata (selanjutnya disebut KUHPerdata). Yayasan merupakan salah satu badan hukum yang bersifat privat dan memiliki batasan (limit) dalam tujuannya, yaitu dalam bidang sosial, keagamaan dan kemanusiaan. Yayasan yang didirikan oleh Lembaga publik (pemerintah) tidak mengubah statusnya sebagai badan hukum privat, sekalipun selaku pendiri adalah organ publik/pejabat publik, Yayasan didirikan tidak mempunyai wewenang public melainkan dalam lingkup hubungan keperdataan (privat) (Simamora, 2012). Yayasan berkarakter sosial nirlaba yang merupakan organisasi sosial non pemerintah yang kegiatannya bersifat karikatif atau bantuan amal langsung dan kegiatan advokasi transformatif (pemberdayaan). Yayasan didirikan oleh perseorangan atau kelompok sesuai Pasal 9 Undang-Undang Nomor 16 Tahun 2001 tentang Yayasan, yang berbunyi: "Yayasan didirikan oleh satu orang atau lebih dengan memisahkan sebagian harta kekayaan pendirinya, sebagai kekayaan awal" 
Ketentuan tersebut menjelaskan bahwa pendirian Yayasan tidak dilakukan dengan dasar adanya suatu perjanjian, karena apabila Yayasan didirikan hanya oleh satu orang, maka tidak akan dilakukan pembuatan perjanjian oleh pendirinya (Hudayanti, 2017). Yayasan dijalankan oleh alat pelengkapnya, di mana terdapat organ dalam Pengurusan Yayasan tersebut yaitu Pembina, Pengurus dan Pengawas. Pembina merupakan organ dalam Yayasan yang memiliki kewenangan atau kekuasaan yang mutlak dalam hal evaluasi dan pengamatan kinerja yang dilakukan Pengurus dan Pengawas sesuai Pasal 28 ayat (2) huruf b Undang-Undang Nomor 16 Tahun 2001 tentang Yayasan, mengenai pengangkatan dan pemberhentian Pengurus dan Pengawas. Bentuk keputusan yang dikeluarkan oleh Pembina Yayasan bersifat subjektif (argumen pribadi). Hal ini dapat menimbulkan adanya penyalahgunaan kekuasaan dalam Pengurusan Yayasan yang dilakukan Pembina. Menurut Henry P. Pangabean (dalam Ais, 2000) menyatakan bahwa Pembina adalah tokoh yang berdedikasi penuh dengan kewenangan yang luar biasa. Pengangkatan Pembina diatur dalam Pasal 28 ayat (3) Undang-Undang Nomor 16 Tahun 2001 tentang Yayasan yang berbunyi: "yang dapat diangkat menjadi anggota Pembina sebagaimana dimaksud dalam ayat (1) adalah orang perseorangan sebagai pendiri Yayasan dan/atau mereka yang berdasarkan keputusan rapat anggota Pembina dinilai mempunyai dedikasi yang tinggi untuk mencapai maksud dan tujuan Yayasan"

Pembina adalah organ dalam Yayasan yang memiliki kewenangan tertinggi dalam hal mengatur Pengurusan Yayasan. Kewenangan sebagai organ tertinggi menjadikan Pembina memiliki kekuasaan untuk menilai hasil kerja Pengurus dan Pengawas dalam setiap tahun (Pasal 28 ayat (2) Undang-Undang Nomor 16 Tahun 2001 tentang Yayasan).

Tanggung jawab Pembina berhubungan dengan tugas dan kewenangannya terdapat dalam Anggaran Dasar dan Anggaran Rumah Tangga Yayasan. Tetapi dalam Undang-Undang Yayasan tidak ditetapkan secara jelas tanggung jawab dari Pembina, karena adanya larangan rangkap jabatan menjadi Pengurus dan Pengawas yang diatur dalam Pasal 29 Undang-Undang Nomor 16 Tahun 2001 tentang Yayasan. Fungsi dan kewenangan yang dimiliki Pembina dilakukan melalui rapat anggota Pembina (Pembina harus lebih dari satu).

Perbuatan atau tindakan hukum yang dilakukan organ Yayasan dapat dibagi dalam beberapa kategori, yaitu: (a) perbuatan organ yang dilakukan dalam batas-batas wewenangnya, dimana badan hukum terikat dan bertanggungjawab. Artinya Pembina Yayasan dalam melakukan kewenangannya sesuai dengan Undang-Undang Nomor 16 Tahun 2001 tentang Yayasan dan Anggaran Dasar Yayasan, maka pembian akan terlepas dari tanggungjawab; (b) perbuatan organ diluar wewenangnya, tetapi kemudian oleh organ yang lebih tinggi atau perbuatan itu menguntungkan badan hukum. Dalam organ Yayasan, Pembina merupakan organ tertinggi, sehingga dalam pengesahan yang dilakukan apabila memiliki dampak baik bagi Yayasan, maka Pembina Yayasan terlepas dari tanggung jawab pribadi; (c) perbuatan organ di luar wewenangnya dengan pihak ketiga beritikad baik yang berakibat merugikan. Badan hukum tidak berhubungan dengan kerugian yang dialami, tetapi organ Yayasan harus dapat membuktikan bahwa tidak bersalah sehingga tidak dibebankan secara pribadi tanggung jawab menanggung; (d) tindakan organ yang merupakan perbuatan melanggar hukum dalam batas-batas wewenangnya. Kegiatan usaha yang dilakukan Yayasan sebagai badan hukum, maka harus bertanggung jawab atas perbuatan melawan hukumnya; (e) tindakan organ yang merupakan perbuatan melanggar hukum di luar wewenangnya. Maksudnya badan hukum atau Yayasan tidak terikat dan yang harus bertanggung jawab adalah organ Yayasan terhadap pihak ketiga; (f) tindakan organ yang merupakan perbuatan melanggar hukum dalam batas-batas wewenangnya tetapi ada kesalahan pribadi dari organ. Artinya apabila Pembina dalam menjalankan kewenangannya melanggar 
hukum, yang mengakibatkan Yayasan harus mengganti rugi terhadap pihak ketiga, maka pihak ketiga dapat tetap menuntut kepada Pembina Yayasan (Rido dalam Priyatno, 2017).

Perbuatan organ dalam batas-batas wewenangnya yang bertindak lalai (melalaikan kewajiban) atau kurang hati-hati yang menimbulkan kerugian bagi badan hukum, maka badan hukum tetap terikat dan ada pertanggungjawaban pribadi. Organ Yayasan dalam menjalankan tugasnya dapat melakukan beberapa kesalahan pribadi, yang dapat mengakibatkan kerugian bagi Yayasan. Dalam hubungan dengan melawan atau melanggar hukum, berdasar Pasal 1365 KUHPerdata menyatakan:

"tiap perbuatan melanggar hukum, yang membawa kerugian kepada seorang lain, mewajibkan orang yang karena salahnya menerbitkan kerugian itu, mengganti kerugian tersebut"

Pelanggaran hukum yang dilakukan organ Yayasan tidak menjadikan Yayasan juga dikatakan melakukan perbuatan hukum, hal ini sesuai asas "societas delinquere non potest" yaitu badan hukum tidak dapat melakukan tindakan pidana (Muladi \& Priyatno, 1992). Kesalahan yang dilakukan organ Yayasan, menjadikan untuk mengganti kerugian tersebut secara pribadi. Pengurus dan Pengawas apabila melakukan kesalahan dengan menjadikan Yayasan mengalami kepailitan maka diharuskan bertanggungjawab atas kerugian tersebut, hal ini diatur dalam Pasal 39 aturan bagi Pengurus dan Pasal 47 bagi Pengawas. Sedangkan Pembina juga merupakan organ dalam Yayasan, tetapi tidak terdapat aturan mengenai bentuk tanggung jawab atas kesalahan yang dilakukan Pembina.

Pembina dalam suatu Yayasan terdiri dari seorang atau lebih sebagai anggota Pembina, yang dalam hal tersebut terdapat ketua Pembina dan anggota Pembina. Tugas Pembina dalam Yayasan yaitu melakukan evaluasi tentang kekayaan, hak dan kewajiban Yayasan, dengan dilakukannya rapat tahunan sesuai Pasal 30 Undang-Undang Nomor 16 Tahun 2001 tentang Yayasan. Apabila suatu Yayasan hanya memiliki seorang Pembina, maka tidak akan diadakan rapat anggota Pembina dan semua keputusan yang diambil oleh Pembina dilakukan secara individu tanpa dilakukan musyawarah (hasil keputusannya dianggap sah dan mengikat). Masa jabatan yang diterima Pembina tidak ditentukan lamanya dan bentuk pemantauan kinerja Pembina tidak diatur dalam Undang-Undang Yayasan. Ketiadaan ketentuan pengaturan mengenai bentuk Pengawasan kewenangan yang dimiliki Pembina dan pemberhentian Pembina menjadikan celah munculnya suatu problematika mengenai kewenangan absolut (mutlak) yang dimiliki Pembina, mengakibatkan Pembina melakukan tindakan sewenang-wenang. Undang-Undang Nomor 16 Tahun 2001 tentang Yayasan tidak dapat mengkoordinasi kemungkinan munculnya suatu masalah dalam pengolahan Yayasan (konsekuensi kesalahan atau kelalaian yang dilakukan Pembina), karena hanya pengaturan tentang Pengurus dan Pengawas yang secara jelas diatur dalam undangundang Yayasan tersebut. Sehingga permasalahan mengenai tanggungjawab dan pemberhentian Pembina, belum dapat terselesaikan secara normatif (hukum) karena belum terdapat aturan hukum positif yang dapat dijadikan landasan yuridis penyelesaian atas permasalahan tersebut.

\section{KESIMPULAN DAN SARAN}

\section{Kesimpulan}

Dari uraian di atas, dapat di tarik kesimpulan bahwa Yayasan merupakan subjek hukum yang berbentuk badan hukum. Organ yang mengoperasikan Yayasan ada 3 yaitu Pembina, Pengurus, dan Pengawas. Dasar hukum berdirinya Yayasan adalah Undang-Undang Nomor 16 Tahun 2001 tentang Yayasan. Dalam peraturan tersebut terdapat kelemahan berupa kekosongan aturan mengenai bentuk kewenangan yang dimiliki Pembina dalam Yayasan, yang terkesan mutlak dan aturan tentang pemberhentian Pembina tidak diatur secara jelas. Hal tersebut menjadikan Pembina 
dapat bertindak sewenang-wenang dan keadilan dalam peraturan tersebut belum tercapai, karena pengaturan terhadap bentuk pertanggungjawaban yang dilakukan organ Yayasan, hanya diperuntukkan oleh Pengurus dan Pengawas, sedangkan Pembina tidak diaturkan bentuk tanggung jawab atas tugasnya. Akibat yuridis dari permasalahan tersebut adalah tidak adanya bentuk penyelesaian hukum karena tidak terdapat aturan yang mengikat.

\section{Saran}

Saran terhadap permasalahan tersebut, penulis berharap agar Indonesia dapat memiliki hukum yang berusaha menciptakan keadilan, kepastian, dan kemanfaatan khususnya dalam pengaturan tentang Yayasan mengenai Pembina Yayasan. Penulis menyarankan bagi pembuat perundangundangan untuk melengkapi kekosongan norma (rechtsvacuum) atas Undang-Undang nomor 16 Tahun 2001 tentang Yayasan mengenai pengaturan bentuk tanggungjawab dan pemberhentian Pembina, agar keadilan, kepastian dan kemanfaatannya dapat terwujud.

Ucapan Terima Kasih (Acknowledgement)

Penulis berterima kasih kepada berbagai pihak yang membantu dan mendukung dalam penelitian dan penelitian ini, yang tidak dapat disebutkan satu persatu oleh penulis.

\section{REFERENSI}

Ais, C. (2000). Tujuan sosial yayasan dan kegiatan usaha bertujuan laba. PT Citra Aditya Bakti. Ali, Z. (2014). Metode penelitian hukum. Sinar Grafika.

Amiruddin, A., \& Asikin, Z. (2016). Pengantar metode penelitian hukum. PT Rajagrafindo Persada. Jakarta.

Aswaratika, L. (2018). Kedudukan yayasan yang belum disesuaikan dengan undang-undang yayasan setelah jangka waktu berakhir. Jurnal Notaire, 1(1), 86. http://dx.doi.org/10.20473/ntr.v1i1.9099.

Diantha, I. M. P. (2016). Metodologi penelitian hukum normatif. PT Kharisma Putra Utama. Jakarta.

Hudayanti, N. (2017), Distribusi aset dan kekayaan yayasan: Perspektif perundang-undangan. Jurnal Al-Daulah, 6(2), 206. https://doi.org/10.24252/ad.v6i2.4877.

Kansil, C. S.T.. (1991). Modul hukum perdata. Pradnya Paramita.

Kitab Undang-Undang Hukum Perdata/KUHPer (Burgerlijk Wetboek).

Marzuki, P. M. (2013). Penelitian hukum. Prenada Media Group.

Muladi, M., \& Priyatno. D. (1992). Pertanggungjawaban korporasi dalam hukum pidana. Penerbit Sekolah Tinggi Ilmu Hukum (STHB).

Priyatno, D. (2017). Sistem pertanggungjawaban pidana korporasi dalam kebijakan legislasi. Kencana.

Prodjodikoro, R. W. (1992). Asas-asas hukum perdata. Sumur Bandung.

Simanjuntak, P. N.H.. (2015). Hukum perdata Indonesia. Kencana.

Simamora, Y. S. (2012). Karakteristik, pengelolaan dan pemeriksaan badan hukum yayasan di $\begin{array}{llll}\text { Indonesia. } \quad J u r n a l & \text { Rechtsvinding, } & 1(2),\end{array}$ http://dx.doi.org/10.33331/rechtsvinding.v1i2.95.

Simatupang, T .H. (2016). Kesadaran badan hukum yayasan pendidikan di Indonesia (persepsi dan kesadaran hukum masyarakat). Jurnal Penelitian Hukum De Jure, 16(3), 277. http://dx.doi.org/10.30641/dejure.2016.V16.277.

Sofwan, S. S. M. (1964). Hukum badan pribadi. PB Gadjah Mada.

Syahrani, R. (1992). Seluk beluk dan asas-asas hukum perdata. Alumni. Bandung.

Tutik, T. T. (2008). Hukum perdata dalam sistem hukum nasional. Kencana. Jakarta.

Undang-Undang Negara Republik Indonesia Tahun 1945. (1945). Indonesia. 
Undang-Undang Nomor 16 Tahun 2001 tentang Yayasan. (2001).

Undang-Undang Nomor 28 Tahun 2004 tentang Perubahan Atas Undang-Undang Nomor 16 Tahun 2001 tentang Yayasan (2004). 